Texas A\&M University- San Antonio

Digital Commons@ Texas A\&M University-San Antonio

History Faculty Publications

College of Arts and Sciences

1977

\title{
An Archaeological Survey on the Xoxocotlan Piedmont, Oaxaca, Mexico
}

\author{
R. D. Mason \\ D. E. Lewarch \\ Michael J. O'Brien \\ Texas AઐM University-San Antonio, Mike.Obrien@tamusa.edu \\ J.A. Neely
}

Follow this and additional works at: https://digitalcommons.tamusa.edu/hist_faculty

Part of the Anthropology Commons

\section{Repository Citation}

Mason, R. D.; Lewarch, D. E.; O'Brien, Michael J.; and Neely, J. A., "An Archaeological Survey on the Xoxocotlan Piedmont, Oaxaca, Mexico" (1977). History Faculty Publications. 13.

https://digitalcommons.tamusa.edu/hist_faculty/13

This Article is brought to you for free and open access by the College of Arts and Sciences at Digital Commons @ Texas A\&M University- San Antonio. It has been accepted for inclusion in History Faculty Publications by an authorized administrator of Digital Commons @ Texas A\&M University- San Antonio. For more information, please contact deirdre.mcdonald@tamusa.edu. 


\title{
AN ARCHAEOLOGICAL SURVEY ON THE XOXOCOTLAN PIEDMONT, OAXACA, MEXICO
}

\author{
ROGER D. MASON \\ DENNIS E. LEWARCH \\ MICHAEL J. O'BRIEN \\ JAMES A. NEELY
}

\begin{abstract}
Surface survey on the piedmont near the present village of Xoxocotlan, Oaxaca, Mexico, has revealed the pattern of prehistoric settlement around an irrigation canal that distributed water from a dammed reservoir located on the flanks of Monte Alban. Intensive systematic collection techniques have permitted quantitative statements to be made about the density of occupation and the contribution of the irrigation system to the food supply of Monte Alban.
\end{abstract}

During the summer of 1973 an intensive survey was conducted around a Late Formative irrigation system near the village of Xoxocotlan in the Valley of Oaxaca, Mexico. The survey area is located on the southeastern piedmont slopes of the mountain of Monte Alban (Fig. 1). The survey was undertaken to clarify the relationship of the irrigation system to the development of Monte Alban as an urban center. Neely (1972) had previously located the irrigation system while carrying out a reconnaissance of Monte Alban.

Studies of water control at Monte Alban were conducted in conjunction with the Valley of Oaxaca Settlement Pattern Project, directed by Richard E. Blanton. Blanton's (1973) survey of Monte Alban provides information on the extent of settlement through time at that large site. Settlement on Monte Alban dates from the beginning of the Late Formative period during the Early Monte Alban I phase (Table 1), and excavations by Marcus Winter (1974) indicate that the site was probably colonized at this time by residents of nearby villages within the Valley of Oaxaca. At its greatest extent during the Late Classic period, the surface area of the site was over $7.5 \mathrm{~km}^{2}$ and included more than 2,300 residential terraces (Blanton 1973) on the slopes of Monte Alban, Monte Alban Chico, El Gallo, and Atzompa (Fig. 1).

The irrigation system (Neely 1972; Neely and O'Brien 1973; Neely and O'Brien n.d.) consists of a dam and a canal which leads from it for a distance of at least two kilometers. The dam is situated in a large barranca below and to the east of the South Platform of Monte Alban's Main Plaza. Approximately $10 \mathrm{~m}$ high at its center and $80 \mathrm{~m}$ in overall length, the structure is V-shaped in plan view with the point of the " $\mathrm{V}$ " directed upstream. The ends of the dam abut a limestone outcrop on either side of the barranca, effectively blocking the channel and impounding water in a large reservoir. Construction material consisted primarily of unmodified boulder fill consolidated with a limestone cement. In addition, the uppermost portion of the construction, approximately one meter in height, was made of cut limestone blocks, fitted together very neatly. A thick limestone plaster was applied to the outer surface of the dam, probably to reduce water loss through seepage.

The canal begins at the south end of the dam and follows the contour of the mountain flank along the side of the barranca. It was found to course along the top of a gently convex piedmont ridge toward the present village of Xoxocotlan. In a few places the canal is chiseled into bedrock but along most of its course it is only visible as a slight depression in the soil. Transverse test excavations indicated two distinct channels within the canal; a smaller one about $30 \mathrm{~cm}$ wide by $12 \mathrm{~cm}$ deep that had been excavated into the side-wall of a larger channel which was about $80 \mathrm{~cm}$ by $25 \mathrm{~cm}$ in size (Neely 1972; Neely and O'Brien 1973; Neely and O'Brien n.d.; cf. Fowler 1969: 212-14). The two channel sizes may have been for the purpose of accommodating differing wet and dry season water volumes. Sherds found in the canal fill suggest that the canal dates from the Late Formative period. The irrigation system also included terraces, especially on the steeper upper portion of the piedmont ridge. These terraces would have made irrigation agriculture more efficient by retaining soil and water in the irrigated area. 


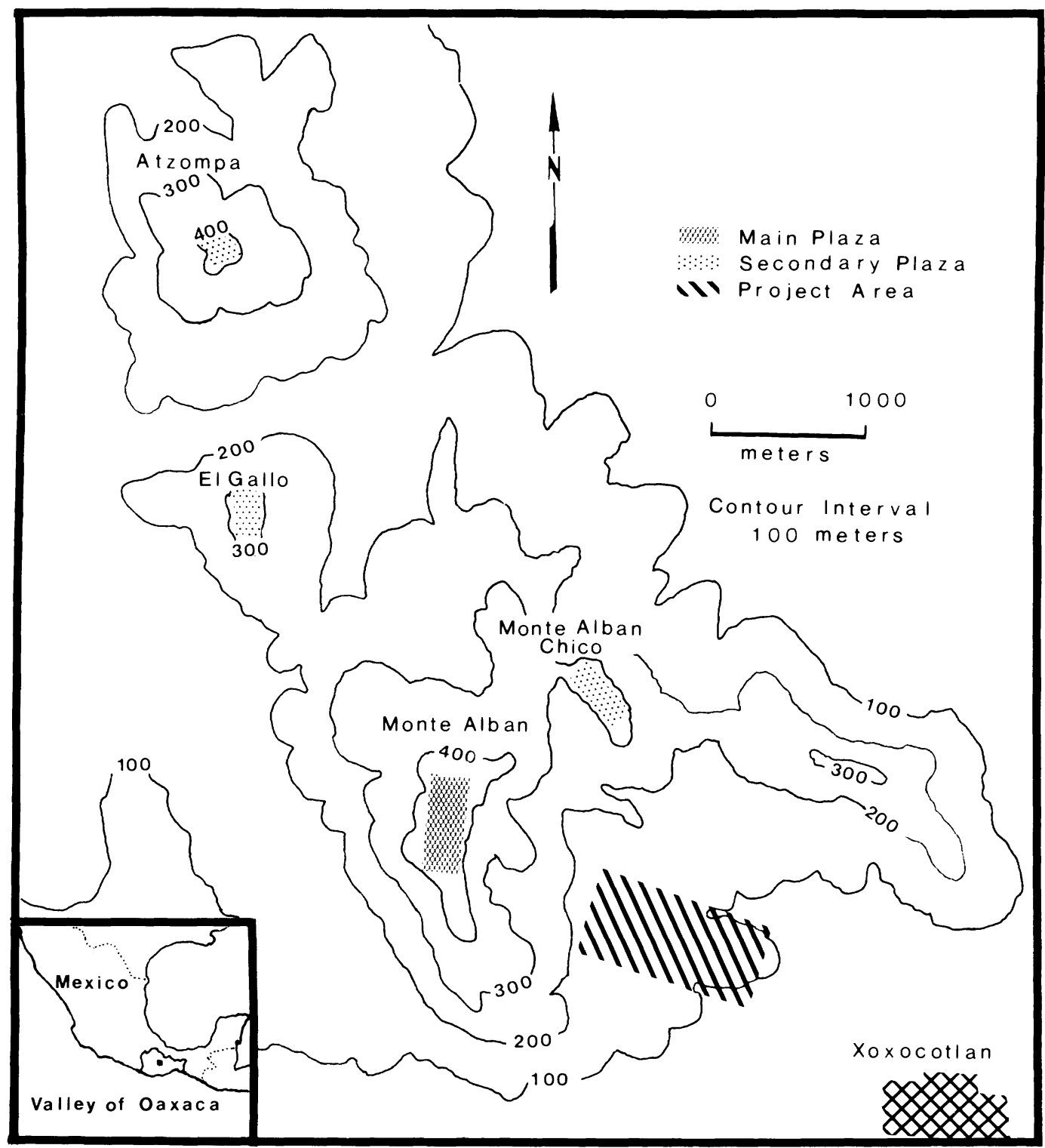

Fig. 1. Map of the Monte Alban region of the Valley of Oaxaca showing the location of the Xoxocotlan Survey Project area. (Adapted from Blanton 1973.)

\section{RESEARCH OBJECTIVES}

The work described in this report was designed to define quantitatively the distribution and temporal duration of settlement around the canal described above. The excavated cross section tests had indicated a Late Formative date for the canal, and consequently raised a question concerning the relationship between the irrigation system and the beginnings of Monte Alban. Specifically, we wished to determine whether or not the irrigation system could have made any significant contribution to the food supply of the inhabitants of Monte Alban. Monte Alban is located on a mountain, and a source of food on its slopes in the piedmont zone would have reduced the need to transport food from the more distant alluvial zone, where, until the need for more intensive crop production developed, canal ir- 
rigation was evidently not required (Flannery and others 1967; Kirkby 1973).

In order to ascertain what contribution the irrigation system could have made to the food supply of Monte Alban, it was necessary to determine the cultivable area of the system and the size of the associated residential area. These were the principal research objectives of the survey. To accomplish these goals, a survey technique was required that would provide quantitative information on the distribution of artifact (i.e., occupational) densities within the system as a whole.

\section{FIELD TECHNIQUES}

For extensive surveys, covering large areas or regions during relatively short periods of time in the field, perhaps the only feasible approach is to collect small (50 to 100 sherds) "grab samples" (Vescelius 1960) from each location or collection unit (such as a site or residential terrace). However, when dealing with a smaller area, such as that comprising the Xoxocotlan irrigation system, more intensive collection techniques, which are described below, can be employed.

Table 1. Chronological chart for the Valley of Oaxaca (Based on Winter, Gaxiola, and Alaniz 1975).

\begin{tabular}{|c|c|c|}
\hline Period & Phase & Years \\
\hline \multirow{3}{*}{ Postclassic } & M. A. V. & A.D. $950-1521$ \\
\hline & M. A. IV & $650-950$ \\
\hline & $--\cdots-----$ & \\
\hline \multirow{2}{*}{ Classic } & M. A. III-B & $450-650$ \\
\hline & M. A. III-A & A.D. $250-450$ \\
\hline \multirow[b]{2}{*}{ Terminal Formative } & --------- & \\
\hline & M. A. II & $\begin{array}{l}\text { A.D. } 250- \\
150 \text { B.C. }\end{array}$ \\
\hline \multirow{2}{*}{ Late Formative } & Late M. A. I & 400-150 B.C. \\
\hline & Early M. A. I & $550-400$ \\
\hline \multirow{2}{*}{ Middle Formative } & $\begin{array}{l}--------- \\
\text { Rosario }\end{array}$ & $700-550$ \\
\hline & Guadalupe & $850-700$ \\
\hline \multirow{2}{*}{ Early Formative } & $\begin{array}{l}\text { San Jose }\end{array}$ & $1150-850$ \\
\hline & Tierras Largas & 1400-1150 B.C. \\
\hline
\end{tabular}

Many of the archaeological surveys carried out thus far in highland Mesoamerica, such as Sanders' (1965) survey of the Teotihuacan Valley, the eastern Valley of Mexico surveys conducted by Parsons (1971) and Blanton (1972), the survey of the Nochixtlan Valley of Oaxaca by Spores (1972), and the Etla Arm survey directed by Varner (1975) in the Valley of Oaxaca, have been extensive in nature and were primarily concerned with plotting the locations of spatial concentrations of artifacts (such as sites). Grab samples were taken principally for temporal placement of the site, and sherd density was often estimated by a subjective visual appraisal. This approach may be contrasted with the technique of systematic surface sampling followed by plotting the distribution of all artifact densities relative to the area surveyed, thus producing a "siteless survey" (Robert C. Dunnell, personal communication; Dancey 1973; Lewarch and Mason 1974; Tolstoy and Fish 1975).

The major difference between the two approaches is in the means of interpreting spatial relationships between units of analysis. Studies emphasizing location use discrete coordinate information such that the units of analysis are the locations of concentrations of artifacts. No information is imparted about the density of artifacts lying between such concentrations. Thus, emphasis on spatial concentrations of artifacts does not provide information about 
the distribution of artifact density, only the discrete locations of artifact densities. The statements which can be made about the area or region as a whole are thus limited when using survey techniques which emphasize locating dense concentrations of artifacts.

In order to avoid these limitations in the Xoxocotlan survey, the entire surface of the ridge which could have been irrigated by water from the canal was taken to be the survey universe and the entire area was mapped and collected regardless of artifact density (Fig. 2). To provide quantitative comparability between all parts of the area, a standardized collecting procedure was required. This was accomplished by collecting all visible rim sherds from every collection unit. To collect all sherds would have required a greater expenditure of time without contributing significantly to the results of the survey since many body sherds cannot be assigned to a particular temporal period or phase. Workers were spaced approximately $3 \mathrm{~m}$ apart while collecting sherds. The workers then made sufficient traverses of each collection unit to cover the entire area of the unit. The well-defined modern fields, that in many cases correspond with prehispanic terraced fields, were used as collection units. These collection units were carefully numbered and recorded on an aerial photo of the area as the survey progressed. This type of collection procedure produces data which allow quantitative comparison between collection units and between temporal periods or phases. This is similar to the procedure recently employed at Teotihuacan and at Coapexco, although these surveys were not truly "siteless" since all collection occurred within an area already defined as a site (see Cowgill 1974; Tolstoy and Fish 1975).

To convert the raw sherd counts per collection unit to a more easily comprehensible form, the SYMAP (Shmidt 1973) computer program (version on file at the Computer Center, University of Washington) was employed. This computer program produced maps indicating the distribution of sherd densities through time within the survey area. Thus, a visual representation of occupational density for each period or phase was available. A second set of SYMAPs which incorporated corrections for vegetational differences was also produced. Most of the collection units were either bare, recently plowed fields or had corn or other crops which covered less than $25 \%$ of the ground surface. However, some collection units had corn over $2 \mathrm{~m}$ high, while others were grass-covered uncultivated or fallow plots. Since it is likely that fewer sherds were collected in units where vegetation covered a large percentage of the ground surface, corrections for the effect of vegetation on sherd density were made. Correction factors were based on two important controlling variables: (1) the type of vegetation present, and (2) the percent of ground surface visible. In order to assure the comparability of all archaeological classes for accurate analysis and meaningful interpretation, correction factors were generated that were unique to the various combinations of the controlling variables for the ceramic collections representing each occupational phase. The corrected sherd density value distributions were then compared with the uncorrected distributions in order to see if the same patterning of the archaeological classes held true. If, in fact, there were differences between the two sets of distributions, then vegetation differences had to be taken into account, along with other possible variables, in order to assess the validity of the patterning and any subsequent interpretations. The method of calculating the correction factors is detailed in the report by O'Brien and others $(1975: 191-97)$. The primary data, other statistical calculations, and the various SYMAPs generated are also to be found in that report.

\section{RESULTS}

The map of the survey area with collection units, terrace walls, structures, and mounds (designated as Fea. 1, S. 1, etc.), and the canal is given in Figure 2. For descriptive purposes, the survey area has been divided into Upper, Middle, and Lower Sectors, as indicated on the map. This figure also illustrates the distribution of rim sherd (i.e., occupational) densities for the Late Monte Alban I phase in terms of three density levels.

Recent research (Flannery 1970; Blanton 1973; Winter 1972, 1974; and others) has resulted in a better understanding of the early ceramic sequence within the Valley of Oaxaca. We feel that this work has provided adequate criteria to distinguish the phases of occupation represented by the ceramic types collected from the surface of our survey area. 


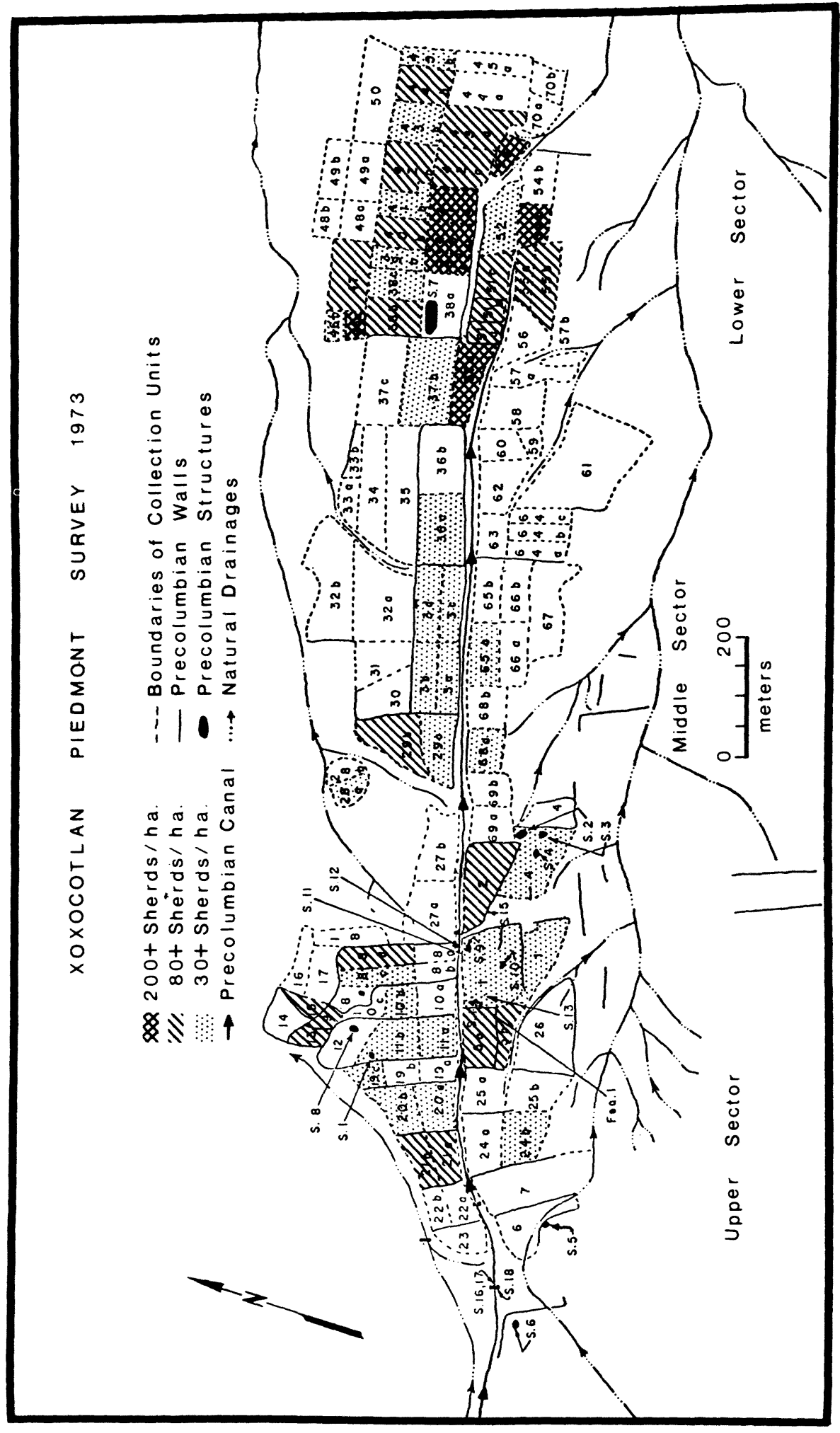

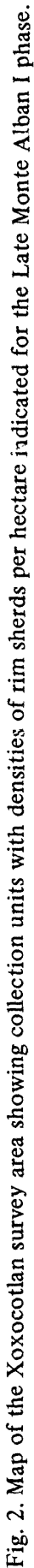


Occupation around the canal began in Early Monte Alban I, peaked in Late Monte Alban I, and declined drastically during the Monte Alban II phase. In all three phases, the densest area of occupation was located on the crest of the ridge in the Lower Sector. The canal, itself, runs along the crest of the gently convex ridge until it reaches the densely occupied Lower Sector. There it was diverted southeastward off of the crest to the side of the ridge, where it runs below and to one side of the area of densest occupation before apparently emptying into an arroyo. During the Late Monte Alban I phase there were also areas of high density in the Upper Sector. High density occupation areas tended to be located on land which was not optimal for agriculture, or which was immediately adjacent to the canal-presumably to meet domestic water demands. For example, the high density area in the Lower Sector is topographically above the canal and therefore could not have easily received water from it for agricultural purposes. High density areas in the Upper Sector are predominantly on the terraces characterized by relatively thin soil overlying bedrock.

High density areas during Late Monte Alban I were collection units from which we recovered 80 or more rim sherds per hectare. These areas probably represent residential zones since they are surrounded by areas with much lower sherd densities (mostly less than 30 rim sherds per hectare). Verification of the proposed correlation between areas of high sherd density and residential zones was made when test excavations in one of these areas in the Upper Sector exposed a house and midden deposit. Collection units with densities greater than 80 rim sherds per hectare occupy 10.2 hectares when corrections for vegetation are taken into account. During Early Monte Alban I, areas having 30 or more rim sherds per hectare were judged to have been residential, based on the surrounding distributions of lower sherd densities. A lower residential zone density is probable for Early Monte Alban I owing to the shorter duration of the phase. Units having more than 30 rim sherds per hectare during Early Monte Alban I cover 2.5 hectares when corrections for vegetation are taken into account.

During Late Monte Alban I, the distribution of sherds in the Middle Sector, which has the most level land and the deepest soil, conforms to what one would expect for irrigation agriculture. That is, there are more sherds closer to the canal than further away, indicating more intensive use of land closer to the canal-land that was probably fertilized with household trash (which would include broken ceramic vessels). This is a practice similar to the calmil system described by Palerm (1955, 1967:36), and evidenced at the irrigation system preserved in travertine at Hierve el Agua, southeast of Mitla, Oaxaca (Neely 1967). However, it differs somewhat from the "classic" calmil village system in that the present work illustrates areas of nucleated settlement adjacent to cultivated fields rather than more dispersed houses, each with its agricultural plot.

The location of mounds with respect to the Late Monte Alban I sherd distribution is also of interest. All mounds are in low density areas directly adjacent to high density areas defined above as residential (Fig. 2). Thus, whether the mounds represent high status residences or ceremonial structures, settlement and activity around the mounds must have been restricted or the area was cleaned periodically. The largest mound, located in the Lower Sector, is $40 \mathrm{~m}$ long, $7 \mathrm{~m}$ wide, and $0.5 \mathrm{~m}$ high. It is in a collection unit with a Late Monte Alban I density of $18 \mathrm{rim}$ sherds per hectare and is adjacent to a collection unit with a density of 361 rim sherds per hectare.

The analysis of the distribution of occupational densities suggests an intra-site or community pattern influenced by an irrigation system. Instead of the usual relatively compact village arrangement characterizing the region during this period of occupation (Flannery 1970; Winter 1972, 1974; Blanton 1973; Kowalewski 1974), the settlement was linear, extending out along the piedmont ridge and paralleling the canal on less productive land.

The cultivable area was defined as being all of the relatively flat land on the ridge top above (i.e., upslope or west of) the point where the canal leaves the ridge and empties into an arroyo. Steep eroded areas on the sides of the ridge were excluded, although some formerly cultivable land may have been eroded away in these areas. The cultivable area corresponds to the area surveyed shown in Figure 2, excluding the residential zones, and totals approximately 50 hectares. 


\section{CONCLUSIONS}

We have determined that the Xoxocotlan irrigation system had a cultivable area of about 50 hectares and a residential zone not exceeding 2.5 hectares during Early Monte Alban I, and 10.2 hectares during Late Monte Alban I. By comparison, settlement on Monte Alban is estimated by Blanton (1973) to have covered between one and two $\mathrm{km}^{2}$ during Early Monte Alban I and between four and $4.5 \mathrm{~km}^{2}$ during Late Monte Alban I. It must be emphasized, however, that these latter figures represent the extent of the sherd scatter for these phases rather than the residential zones as defined quantitatively for the Xoxocotlan settlement. In any case, these figures show that the productive capacity of the irrigation system was quite small in relation to the food requirements of a settlement several square kilometers in area.

It is also possible to make some population estimates which, although tenuous, are even more indicative of the differences in scale between the irrigation system and the Monte Alban settlement. The population figures given below should be taken only as indicative of the order of magnitude involved, not as absolute. Piedmont irrigation agriculture in the Valley of Oaxaca as practiced today (without manuring) in the village of Santo Tomas Mazaltepec produces enough corn to support five persons per hectare of land cultivated (Brennan 1971; Granskog 1974). Assuming the applicability of this data to the Xoxocotlan piedmont area, the Xoxocotlan irrigation system would have supported up to 250 persons on its 50 hectare cultivable area. Given the smaller corn cob sizes in the past (Kirkby 1973, Fig. 48a), this figure should be taken as a maximum.

Winter (1972) gives a figure of ten households per two to three hectare Middle Formative village in the Valley of Oaxaca, based on his excavations. This gives a population density of approximately 20 persons per hectare (at five persons per household). If this figure is applied to the Xoxocotlan settlement, the 2.5 hectare Early Monte Alban I residential area had a population of about 50 people. During Late Monte Alban I, a population of about 200 can be estimated for the 10.2 hectare residential area of that phase. By contrast, if the residential zone of Monte Alban totaled several square kilometers during these two phases, then a population in the thousands is indicated for that site.

The difference between the population of 50 estimated for the Xoxocotlan irrigation community in Early Monte Alban I times and the ability of the system to support 250 persons indicates that it would have been possible to produce a surplus for consumption on Monte Alban during the Early Monte Alban I phase, assuming there was sufficient incentive to do so. During Late Monte Alban I times it seems likely that only a small surplus could have been produced by the Xoxocotlan community. Therefore, considering the data at hand, the total yield of the Xoxocotlan irrigation community at any time during its existence probably did not make a significant contribution to the food requirements of Monte Alban's large population.

As the Xoxocotlan irrigation system evidently was not a significant part of the food procurement system of Monte Alban, the reasons for the establishment of the irrigation settlement are open to speculation. We hypothesize, however, that there was an Early Monte Alban I ceremonial-administrative center on Monte Alban before the establishment of the Xoxocotlan irrigation settlement. The latter may well represent a colonization of the piedmont below Monte Alban by people from a valley floor village for whom resettlement and the practice of agriculture directly adjacent to the new ceremonial-administrative center was advantageous. Construction of an irrigation system based on run-off requires a much greater labor investment than does a system based on a perennial water source. If a dam is used, it must be large and impermeable rather than merely diversionary and the distance between the dam and the best agricultural land may be greater, requiring a long canal. Irrigation systems based on perennial water sources, and roughly contemporaneous with the Xoxocotlan system, have been found and are indicated elsewhere in the Valley (Neely 1967; Kirkby 1973; Marcus C. Winter, personal communication). In light of this evidence for engineering and technological competence to construct more efficient irrigation systems, the presence of the Xoxocotlan system appears as an anomaly. Therefore, it seems likely that the colonization of the Xoxocotlan piedmont by agriculturalists during the Early Monte Alban I phase was probably 
contingent upon, if not a direct result of, the pre-existence of a powerful stimulus in the form of the ceremonial-administrative center of Monte Alban.

Acknowledgments. This project would not have been possible without the assistance of the following individuals and organizations. The encouragement and cooperation of Richard E. Blanton, director of the Valley of Oaxaca Settlement Pattern Project, and Kent V. Flannery, director of the Valley of Oaxaca Human Ecology Project, were most appreciated. The fieldwork was accomplished under the auspices of Blanton's permit as a segment of the Valley of Oaxaca Settlement Pattern Project. The assistance of Manuel Esparza Camargo, Director of the Centro Regional de Oaxaca of the Instituto Nacional de Antropologia e Historia, is gratefully acknowledged. Special thanks are due John and Melissa Keane, who were also members of the project, and Marcus Winter, who provided invaluable assistance as a consultant during the ceramic analysis. Jerry Jermann assisted us with the SYMAP program and read the manuscript; his comments were extremely helpful. Financial sponsorship of this project was provided by the Institute of Latin American Studies of the University of Texas at Austin by means of a Summer Faculty Research Grant to Neely and an E. D. Farmer Fellowship to O'Brien.

Blanton, Richard E.

1972 Prehispanic settlement patterns of the Ixtapalapa Peninsula region, Mexico. Pennsylvania State University Occasional Papers in Anthropology 6.

1973 The valley of Oaxaca settlement pattern project. Report submitted to the National Science Foundation, Washington, D.C., and the Instituto Nacional de Antropologia e Historia, Mexico, D.F.

Brennan, Curtiss

1971 Modern Oaxacan agriculture and prehispanic Mesoamerican subsistence systems. Manuscript, Department of Anthropology, University of Texas at Austin.

Cowgill, George

1974 Quantitative studies of urbanization at Teotihuacan. In Mesoamerican archaeology: new approaches, edited by Norman Hammond, pp. 363-96. University of Texas Press, Austin. Dancey, William S.

1973 Prehistoric land use and settlement patterns in the Priest Rapids area, Washington. Ph.D. dissertation, Department of Anthropology, University of Washington. University Microfilms, Ann Arbor.

Flannery, Kent V. (editor)

1970 Preliminary archaeological investigations in the valley of Oaxaca, 1966-1969. Report submitted to the National Science Foundation, Washington, D.C., and the Instituto Nacional de Antropologia e Historia, Mexico, D.F.

Flannery, Kent V., Anne V. T. Kirkby, Michael J. Kirkby, and Aubrey W. Williams, Jr.

1967 Farming systems and political growth in ancient Oaxaca. Science 158:445-54.
Fowler, Melvin L.

1969 A Preclassic water distribution system in Amalucan, Mexico. Archaeology 22:208-15.

Granskog, Jane

1974 Efficiency in a Zapotec Indian agricultural village. Ph.D. dissertation, Department of Anthropology, University of Texas at Austin. University Microfilms, Ann Arbor.

Kirkby, Anne V. T.

1973 The use of land and water resources in the past and present Valley of Oaxaca, Mexico. University of Michigan, Museum of Anthropology, Memoirs 1.

Kowalewski, Stephan A.

1974 Ancient settlement patterns in the central valley of Oaxaca, Mexico. Paper presented at the 73rd Annual Meeting of the American Anthropological Association, Mexico, D.F.

Lewarch, Dennis E., and Roger D. Mason

1974 Survey techniques used to define a Late Formative irrigation system in the valley of Oaxaca, Mexico. Paper presented at the 73rd Annual Meeting of the American Anthropological Association, Mexico, D.F.

Neely, James A.

1967 Organizacion hidraulica y sistemas de irrigacion prehistoricos en el Valle de Oaxaca. Boletin del Instituto Nacional de Antropologia e Historia 27:15-17.

1972 Prehistoric domestic water supplies and irrigation systems at Monte Alban, Oaxaca, Mexico. Paper presented at the 37th Annual Meeting of the Society for American Archaeology, Miami.

Neely, James A., and Michael J. O'Brien

1973 Irrigation and settlement nucleation at Monte Alban: a test of models. Paper presented at the 38th Annual Meeting of the Society for American Archaeology, San Francisco.

n.d. Prehistoric domestic water supplies, water control, and irrigation systems at Monte Alban, Oaxaca, Mexico. In The prehistory of Monte Alban, Oaxaca, Mexico (tentative title), edited by Richard E. Blanton. Academic Press, New York (accepted for publication, ms. 1976).

O'Brien, Michael J., Roger D. Mason, Dennis E. Lewarch, and James A. Neely

1975 A Late Formative irrigation settlement below Monte Alban: survey and excavation on the Xoxocotlan piedmont, Oaxaca, Mexico. Manuscript, Latin American Collection, Institute of Latin American Studies, University of Texas at Austin.

Palerm, Angel

1955 The agricultural basis of urban civilization in Mesoamerica. In Irrigation civilizations: a comparative study, edited by Julian Steward, pp. 28-42. Pan American Union, Social Science Monographs 1.

1967 Agricultural systems and food patterns. In Handbook of Middle American Indians, edited by R. Wauchope and M. Nash, 6:26-52. University of Texas Press, Austin.

Parsons, Jeffrey R.

1971 Prehistoric settlement patterns in the 
Texcoco region, Mexico. Museum of Anthropology, University of Michigan, Memoirs 3.

Sanders, William T.

1965 The cultural ecology of the Teotihuacan Valley. Department of Sociology and Anthropology, Pennsylvania State University, University Park.

Shmidt, Allan

1973 Synagraphic mapping program (SYMAP). Lab-Log 3-5. Laboratory for Computer Graphics and Spatial Analysis, the Graduate School of Design, Harvard University, Cambridge, MA.

Spores, Ronald

1972 An archaeological settlement survey of the Nochixtlan Valley, Oaxaca. Vanderbilt University Publications in Anthropology 1.

Tolstoy, Paul, and Suzanne K. Fish

1975 Surface and subsurface evidence for community size at Coapexco, Mexico. Journal of Field Archaeology 2:97-104.

Varner, Dudley M.

1975 Settlement processes in the Etla Arm, Val- ley of Oaxaca, Mexico. Paper presented at the 40th Annual Meeting of the Society for American Archaeology, Dallas.

Vescelius, G. S.

1960 Archaeological sampling: a problem of statistical inference. In Essays in the science of culture in honor of Leslie A. White, edited by Gertrude E. Dole and Robert L. Carneiro, pp. 457-70. Crowell, New York.

Winter, Marcus $\mathrm{C}$.

1972 Tierras Largas: a Formative community in the valley of Oaxaca, Mexico. Ph.D. dissertation, Department of Anthropology, University of Arizona. University Microfilms, Ann Arbor. 1974 Residential patterns at Monte Alban, Oaxaca, Mexico. Science 186:981-87.

Winter, Marcus C., Margarita Gaxiola, and Adriana Alaniz

1975 Secuencia arqueologica del Valle de Oaxaca. Seccion de Arqueologica, Centro Regional de Oaxaca, Instituto Nacional de Antropologia e Historia, Oaxaca. 